\title{
GENETIC ASPECTS OF DEVELOPMENT AND PROGRESSION OF CONGESTIVE HEART FAILURE IN PATIENTS WITH ISCHEMIC HEART DISEASE AND OBESITY*
}

\author{
O. I. Kadykova \\ Kharkiv National Medical University, Kharkiv \\ kadikova.olga@mail.ru
}

Ischemic heart disease is still considered to be a significant health care problem in many countries due to high mortality rate and unfavorable prognosis [1]. Besides, according to the data of epidemiological studies, the number of patients suffering from congestive heart failure is constantly increasing. Thus, the problem of early presymptomatic diagnosis does not tend to be irrelevant, but, on the contrary, should be resolved immediately. The promising direction is the study of a human genome with the following estimation of candidate genes of different cardiovascular diseases [2].

Among the wide range of candidate genes, structural polymorphism of which may have a prognostic value in development and progression of congestive heart failure, special attention in current studies is directed to genes of components of rennin-angiotensin-aldosteron system and counterregulatory systems, including $\beta$-adrenoreceptors genes [3].

The gene of $\beta_{2}$-adrenoreceptors is located on 5q31-32 chromosome. The significant ones are allelic polymorphisms Gly16Arg, Gln27Glu, Val34Met and Thr164Ile, Gly16Arg and Gln27Glu [4]. These polymorphous variants are anticipated to be able to be of great importance in clinical course of congestive heart failure but their role should be studied further.

Purpose of the study is to estimate influence of allelic polymorphism Gln27Glu on $\beta_{2}$-adrenoreceptors gene in patients with ischemic heart disease and obesity on development and progression of congestive heart failure and systolic dysfunction of the left ventricle.

\section{MATERIALS AND METHODS}

The study involved 222 patients with ischemic heart disease and obesity who were undergoing treatment at Cardiology Department of health care communal enterprise Kharkiv Municipal Clinical Hospital 27 which is the basic health institution of Internal Medicine De-

\footnotetext{
*The research was carried out as part of investigation work at the Department of Internal Medicine № 2, Clinical Immunology and Allergology at Kharkiv National Medical University, Ministry of Health of Ukraine «Neurohumoral effects on the progression of chronic heart failure in patients with hypertension and coronary heart disease with renal dysfunction and anemic syndrome» (State registration number: 0111U001395).

Institution, which financed the research: Ministry of Health of Ukraine.

The authors assume responsibility for the published work.

The authors guarantee absence of competing interests and their own financial interest when carrying out the research and writing the article.

The manuscript was received by the editorial staff 15.12.2015.
} 
partment № 2 and Department of Immunology and Allergology of Kharkiv National Medical University of Ministry of Health of Ukraine. All patients with ischemic heart disease were divided into three groups depending on functional class (FC) of congestive heart failure: the subgroup 1 was represented by the patients with congestive heart failure of FC I $(n=50)$, the subgroup 2 included patients with congestive heart failure of FCII $(n=118)$ and the patients with congestive heart failure of FC III-IV $(n=54)$ belonged to the subgroup III. The control group was represented by 35 apparently healthy people. The groups were compared on the basis of age and sex. The study did not enroll patients with concomitant diseases of the organs of the respiratory and digestive systems, the kidneys and patients with oncological diseases.

The diagnosis was made in accordance with the valid orders of Ministry of Health of Ukraine.

All patients underwent general clinical and instrumental examinations. Echocardiographic tests were carried out in accordance with $\mathrm{H}$. Feigenbaum standard method by means of RADMIR (Ultima PRO 30) ultrasonic unit (Kharkiv, Ukraine).

The study of allelic polymorphism of Gln27Glu of $\beta_{2}$-adrenoreceptors gene was conducted using the method of polymerase chain reaction with electrophoretic detection of the findings by means of SNP-EXPRESS assay kits produced by LLC innovation and research company Lytech (Russian Federation). DNA purification was carried out due to DNA-express-blood reagent produced by LLC innovation and research company Lytech (Russian Federation) according to the provided instructions. Validity of arrangement of frequencies of genotypes was assessed through correspondence of Hardy-Weinberg equation (pi2 +2 pipj $+\operatorname{pj} 2=1)$. According to Declaration of Helsinki all patients were informed as for conducting of clinical study and they gave their consent to determine polymorphism of the gene in question.

The statistical processing of the data was performed by means of Statistica package, Version 6.0. In order to compare arrangement of frequencies of allels and genotypes between the groups, Pearson and Fisher $\chi^{2}$ criteria were used. To estimate a relative risk of development of diseases, the ratio of chances was measured. As absence of associations, the ratio of chances $=1$ was considered; as positive association - the ratio of chances $>1$; as negative association of allel or genotype with disease (low risk of development of the disease) the ratio of chances $<1$ was considered. The confidence interval (CI) is a range within which the prognostic value of the ratio of chances with $95 \%$ confidence is located. The statisticallyvalid differences were those ones in $p<0.05$.

\section{RESULTS AND DISCUSSION}

Presence of $\mathrm{C}$ allel of polymorphous locus Gln27Glu of $\beta_{2}$-adrenoreceptors gene in patients with ischemic heart disease and concomitant obesity was associated with decreased risk of development of congestive heart failure (the ratio of chances $=2.32,95 \%$ $\left.\mathrm{CI}=[1.18-4.56], \chi^{2}=7.65 ; p<0.05\right)($ Table 1$)$.

The findings of the study of influence of polymorphous variants of $\beta_{2}$-adrenoreceptors gene on progression of congestive heart fail-

$\mathrm{T}$ a b l e 1

The role of allels $\mathrm{C}$ and G polymorphism Gln27Glu of $\beta_{2}$-adrenoreceptors gene in development of congestive heart failure in patients with ischemic heart disease and obesity

\begin{tabular}{c|c}
\hline \multirow{2}{*}{ Genetic markers } & $\begin{array}{c}\text { Ratio of chances } \\
\mathbf{( 9 5} \mathbf{~} \mathbf{C I})\end{array}$ \\
\hline \multirow{2}{*}{ Allel C } & $2.32(1.18-4.56)$ \\
\cline { 2 - 2 } & $\chi^{2}=7.65 ; p<0.05$ \\
\hline
\end{tabular}


ure (according to NYHA) are presented in Table 2.

The data which have been obtained show absence of influence of polymorphous variants of $\beta_{2}$-adrenoreceptors gene on progression of congestive heart failure (according to NYHA) in patients with ischemic heart disease and obesity $(p>0.05)$. Therefore, almost the same frequency was typical for carriership of allel C polymorphism Gln27Glu of $\beta_{2}$-adrenoreceptors gene in patients with ischemic heart disease and obesity, i.e. $32 \%$, $34.75 \%$ and $31.48 \%$; concerning carriership of allel $G$ the same tendency was observed: $68 \%, 65.25 \%$ and $68.52 \%$ in patients with congestive heart failure I, II and III-Iv respectively. Different genotypes $(\mathrm{C} / \mathrm{G}$, $\mathrm{C} / \mathrm{C}, \mathrm{G} / \mathrm{G}$ ) of polymorphism Gln27Glu of $\beta_{2}$-adrenoreceptors gene in patients with ischemic heart disease and obesity depending on FC of congestive heart failure had almost the same values $(30 \%, 33.05 \%$ and $33.33 \%$ for $\mathrm{C} / \mathrm{G}$ genotype in patients with congestive heart failure of FC I, II i III-IV respectively; $33 \%, 33.90 \%$ and $31.48 \%$ for $\mathrm{C} / \mathrm{C}$ genotype; $37 \%, 33.05 \%$ and $35.19 \%$ for $\mathrm{G} / \mathrm{G}$ genotype, $p>0.05)$.

Arrangement of frequency of allels and genotypes of $\beta_{2}$-adrenoreceptors gene depending on left ventricular ejection fraction (LVEF) in patients with congestive heart failure associated with ischemic heart disease and concomitant obesity is presented in Table 3.

According to the findings of the study conducted, in patients with ischemic heart disease and obesity with preserved inotropic function of the myocardium and systolic dysfunction of the left ventricle, arrangement of frequencies of allels and genotypes of polymorphism Gln27Glu of $\beta_{2}$-adrenoreceptors gene was characterized by smooth nature without statistically-valid differences.

\section{Frequency of detection of allels and genotypes of $\beta_{2}$-adrenoreceptors gene depending on FC of congestive heart failure in patients with} ischemic heart disease and obesity

\begin{tabular}{l|c|c|c}
\hline \multicolumn{1}{c|}{ Genetic markers } & $\begin{array}{c}\text { Subgroup 1 } \\
\text { Congestive heart } \\
\text { failure of FC I } \\
(\boldsymbol{n = 5 0 )}\end{array}$ & $\begin{array}{c}\text { Subgroup 2 } \\
\text { Congestive heart } \\
\text { failure of FC II } \\
(\boldsymbol{n}=\mathbf{1 1 8})\end{array}$ & $\begin{array}{c}\text { Subgroup 3 } \\
\text { Congestive heart } \\
\text { failure of FC III-IV } \\
(\boldsymbol{n}=\mathbf{5 4})\end{array}$ \\
\hline Allel Gln (C) & $16(32 \%)$ & $41(34.75 \%)$ & $17(31.48 \%)$ \\
\hline Allel Glu (G) & $34(68 \%)$ & $77(65.25 \%)$ & $37(68.52 \%)$ \\
\hline Genotype Gln/Glu (C/G) & $15(30 \%)$ & $39(33.05 \%)$ & $18(33.33 \%)$ \\
\hline Genotype Gln/Gln (C/C) & $16(33 \%)$ & $40(33.90 \%)$ & $17(31.48 \%)$ \\
\hline Genotype Glu/Glu (G/G) & $19(37 \%)$ & $39(33.05 \%)$ & $19(35.19 \%)$ \\
\hline
\end{tabular}

Frequency of detection of allels and genotypes of $\beta_{2}$-adrenoreceptors gene depending on left ventricular ejection fraction in patients with ischemic heart disease and obesity

\begin{tabular}{l|c|c}
\hline \multicolumn{1}{c|}{ Genetic markers } & $\begin{array}{c}\text { Subgroup 1 } \\
\text { Ejection } \\
\text { fraction }>\mathbf{4 5} \% \\
(\boldsymbol{n}=\mathbf{1 0 1})\end{array}$ & $\begin{array}{c}\text { Subgroup 2 } \\
\text { Ejection } \\
\text { fraction }<\mathbf{4 5} \% \\
(\boldsymbol{n}=\mathbf{1 2 1})\end{array}$ \\
\hline Allel Gln (C) & $27(26.73 \%)$ & $31(25.62 \%)$ \\
\hline Allel Glu (G) & $74(73.27 \%)$ & $90(74.38 \%)$ \\
\hline Genotype Gln/Glu (C/G) & $34(33.67 \%)$ & $40(33.06 \%)$ \\
\hline Genotype Gln/Gln (C/C) & $35(34.65 \%)$ & $39(32.23 \%)$ \\
\hline Genotype Glu/Glu (G/G) & $32(31.68 \%)$ & $42(34.71 \%)$ \\
\hline
\end{tabular}


Therefore, the obtained data show absence of influence of different allels and genotypes of Polymorphism Gln27Glu of $\beta_{2}$-adrenoreceptors gene on development of ischemic heart disease, progression of congestive heart failure and systolic dysfunction of the left ventricle like the findings of other researchers $[5,6]$, who have proved that polymorphous variants of $\beta_{2}$-adrenoreceptors gene (Gln27Glu) were not connected with risk of development of congestive heart failure and its prognosis. Other researchers obtained the data [7], which tend to specify that the genotype Gln27Glu of $\beta_{2}$-adrenoreceptors gene was more frequently typical for patients with congestive heart failure in comparison with the control group.

The findings of the study concerning detection of interrelation of polymorphism of $\beta_{2}$-adrenoreceptors with the course of ischemic heart disease are quite controversial. In the study conducted by S. M. Wallerstedt the connection of carriership of Arg16Arg, Glu27Glu, Gly16Gly allels with MI has not been found [8].
According to D. E. Lanfear's findings, in patients after MI, who received treatment by means of blockers of $\beta_{2}$-adrenoreceptors and had Gly16Gly and Glu27Glu haplotypes, mortality rate was lower than in patients with other allelic variants [9]. In accordance with the data obtained by S. R. Heckbert Glu27Glu allel is also connected with lower risk of development of acute myocardial infarction in elderly patients [10].

It has been established that patients of Glu27Glu homozygote are in the group of sudden death [11] but the factor which leads to it is still not clear: either it is influence of blockers of $\beta_{2}$-adrenoreceptors on sudden coronary death, or it is congenital protection of $\beta_{2}$-adrenoreceptors in relation to ventricular arrhythmia [12].

However, the interrelation between obesity and carriership of $\mathrm{G}$ allel and $\mathrm{G} / \mathrm{G}$ genotype of polymorphism Gln27Glu of $\beta_{2}$-adrenoreceptors gene in patients with ischemic heart disease has been established by means of our study.

\section{CONCLUSIONS}

1. Presence of allel $\mathrm{C}$ of polymorphous locus Gln27Glu of $\beta_{2}$-adrenoreceptors gene in patients with ischemic heart disease with concomitant obesity was connected with decreased risk of development of congestive heart failure.

2. According to findings of the study conducted, association of progression of chronic cardiac failure in patients with ischemic heart disease and obe- sity with polymorphous variants of $\beta_{2}$-adrenoreceptors gene (Gln27Glu) has not been established.

3. Arrangement of frequency of allels and genotypes of polymorphism Gln27Glu of $\beta_{2}$-adrenoreceptors gene in patients with ischemic heart disease and obesity did not tend to change depending on inotropic function of the myocardium of the left ventricle.

\section{REFERENCES}

1. McMurray J, Adamopoulos S, et al. Eur Heart J 2012; 33:1787-1847.

2. Goldschmidta PJ, Dong C, Daaid Seo D, et al. Curr Atheroscler Rep 2012; 14(3):201-210.

3. Lee JK, Wu CK, Tsai CT, et al. Pharmacogenet Genomics 2013; 23(4):181-189.

4. Brodde OE. Phrmacol Ther 2008; 117:1-29.

5. Yancy CW. N Engl J Med 2001; 344:1358-1364.

6. Covolo L, Gelatti U, Metra M, et al. Eur Heart J 2004; 25:1534-1541.
7. Liggett SB, Wagoner LE, Craft LL, et al. J Clin Invest 1998; 102:1534-1539.

8. Wallerstedt SM, Eriksson AL, Ohlsson C, et al. Hum Genet; 2005; 19:705-708.

9. Lanfear DE, Jones PG, Marsh S, et al. Am Med Assoc 2005; 294:1526-1533.

10. Heckbert SR, Hindorff LA, Edwards KL, et al. Circulation 2003; 107:2021-2024.

11. Sotoodehnia N, Siscovick DS, Vatta M, et al. Circulation 2006; 113:1842-1848.

12. Liggett S. Circulation 2006; 113:1818-1820. 


\title{
ГЕНЕТИЧНІ АСПЕКТИ РОЗВИТКУ ТА ПРОГРЕСУВАННЯ ХРОНІЧНОÏ СЕРЦЕВОÏ НЕДОСТАТНОСТІ У ХВОРИХ НА ІШЕМІЧНУ ХВОРОБУ СЕРЦЯ Й ОЖИРІННЯ
}

\author{
Кадикова О I.
}

Харківсъкий націоналъний медичний університет, м. Харків

kadikova.olga@mail.ru

\begin{abstract}
У статті встановлено вплив алельного поліморфізму Gln27Glu гена $\beta_{2}$-адренорецепторів у хворих з ішемічною хворобою серця й ожирінням на розвиток і прогресування хронічної серцевої недостатності та систолічної дисфункції лівого шлуночка шляхом обстеження 222 хворих. Наявність C алеля поліморфного локусу Gln27Glu гена $\beta_{2}$-адренорецепторів у хворих на ішемічну хворобу серця з супутнім ожирінням була пов'язана зі зниженням ризику розвитку хронічної серцевої недостатності $(p<0,05)$. Отримані у ході дослідження дані демонструють відсутність впливу поліморфних варіантів гена $\beta_{2}$-адренорецепторів на прогресування хронічної серцевої недостатності у хворих на ішемічну хворобу серця й ожиріння $(p>0,05)$.
\end{abstract}

$\mathrm{K}$ л ю ч о в і с л о в а: хронічна серцева недостатність, ішемічна хвороба серця, ожиріння, Gln27Glu ген $\beta_{2}$-адренорецепторів.

\section{ГЕНЕТИЧЕСКИЕ АСПЕКТЫ РАЗВИТИЯ И ПРОГРЕССИРОВАНИЯ ХРОНИЧЕСКОЙ СЕРДЕЧНОЙ НЕДОСТАТОЧНОСТИ У БОЛЬНЫХ ИШЕМИЧЕСКОЙ БОЛЕЗНЬЮ СЕРДЦА И ОЖИРЕНИЕМ}

Кадыкова О.И.

Харъковский националъный медицинский университет, г. Харъков kadikova.olga@mail.ru

В статье установлено влияние аллельного полиморфизма Gln27Glu гена $\beta_{2}$-адренорецепторов у больных ишемической болезнью сердца и ожирением на развитие и прогрессирование хронической сердечной недостаточности и систолической дисфункции левого желудочка путем обследования 222 больных. Наличие C аллеля полиморфного локуса Gln $27 \mathrm{Glu}$ гена $\beta_{2}$-адренорецепторов у больных ишемической болезнью сердца с сопутствующим ожирением была связана со снижением риска развития хронической сердечной недостаточности $(p<0,05)$. Полученные в ходе исследования данные демонстрируют отсутствие влияния полиморфных вариантов гена $\beta_{2}$-адренорецепторов на прогрессирование хронической сердечной недостаточности у больных ишемической болезнью сердца и ожирением $(p>0,05)$.

К л ю ч е в ы е с л о в а: хроничечкая сердечная недостаточность, ишемическая болезнь сердца, ожирение, Gln27Glu ген $\beta_{2}$-адренорецепторов.

\section{GENETIC ASPECTS OF DEVELOPMENT AND PROGRESSION OF CONGESTIVE HEART FAILURE IN PATIENTS WITH ISCHEMIC HEART DISEASE AND OBESITY}

\author{
O. I. Kadykova
}

Kharkiv National Medical University, Kharkiv kadikova.olga@mail.ru

In this article elucidated the influence of allelic polymorphism of Gln27Glu of $\beta_{2}$-adrenoceptors gene on patients that have coronary heart disease and obesity on the expansion and progression of congestive heart failure and left ventricular systolic dysfunction by surveying 222 patients. Presence of $\mathrm{C}$ allel of polymorphous locus Gln27Glu of $\beta_{2}$-adrenoreceptors gene in patients with ischemic heart disease and concomitant obesity was associated with decreased risk of development of congestive heart failure $(p<0.05)$. The obtained data shown the absence of influence of polymorphous variants of $\beta_{2}$-adrenoreceptors gene on progression of congestive heart failure in patients with ischemic heart disease and obesity $(p>0.05)$.

K e y w o r d s: congestive heart failure, ischemic heart disease, obesity, Gln27Glu of $\beta_{2}$-adrenoreceptors gene. 